\title{
Hypersexuality and pharmacological treatment options
}

\author{
Hiperseksualność i farmakologiczne możliwości jej leczenia \\ Beata Kocyan ${ }^{1,2}$, Anna Knapik ${ }^{1,2}$, Martyna Kozłowska ${ }^{1,2}$, Ewa Martyniak ${ }^{1}$, \\ Grzegorz Brożek², Marek Krzystanek ${ }^{1}$
}

\section{ABSTRACT}

Objectives. There are no standardised guidelines regarding the pharmacotherapy of compulsive sexual behaviour. The paper aims to review the available literature

\footnotetext{
CORRESPONDENCE ADDRESS / ADRES DO KORESPONDENCJI

prof. dr hab. n. med. i n. o zdr. Marek Krzystanek

Śląski Uniwersytet Medyczny w Katowicach

Katedra i Klinika Psychiatrii i Psychoterapii

ul. Ziołowa 45/47, 40-635 Katowice

email: krzystanekmarek@gmail.com

- seksoholizm

uzależnienia behawioralne

- farmakoterapia
}

concerning the treatment of excessive sexual activity disorders. Specific mechanisms underlying hypersexuality and the consequent potential differences in its treatment were considered.

Literature review. The classification of sexual disorders related to excessive sexual activity is rather problematic. Both DSM-5 and ICD-11 lack in a homogenous classification of this disorder. Currently, the safest and most beneficial drugs for patients with non-paraphilic disorders seem to be SSRI medications. Drugs presenting an antiandrogenic action (LHRH) are not recommended due to their side effects, apart from cases proceeding with severe symptoms. Promising results were obtained in a trial with naltrexone; yet, the study did not fulfil methodological norms. Other medications used in the treatment of hypersexuality are of minor importance; however, they may be used especially when psychiatric comorbidities are present.

Conclusions. The best effects in the treatment of compulsive sexual behaviour are obtained with the combination of psychotherapy and SSRI drugs. Few methodologically correct studies have been performed. Most studies are carried out on small groups and fail to use methods which would enable to compare various therapeutic options. Research on the pharmacotherapy of non-paraphilic hypersexuality should be continued, especially regarding drugs which may act on the obsessive-compulsive mechanism. 


\section{STRESZCZENIE}

Cel. Nie ma jednoznacznych wytycznych dotyczących farmakoterapii kompulsywnych zachowań seksualnych. Praca ma na celu przegląd dostępnego piśmiennictwa z zakresu leczenia zaburzeń związanych z nadmierną aktywnością seksualną. W szczególności skupiono się na różnych mechanizmach prowadzących do występowania patologicznej hiperseksualności i związanych z tym potencjalnych różnicach w terapii.

Przegląd piśmiennictwa. Klasyfikacja zaburzeń seksualnych związanych z nadmierną aktywnością jest bardzo problematyczna. Brak jednoznacznej klasyfikacji tego zaburzenia zarówno w DSM-5, jak i w ICD-11. Obecnie lekami o najwyższym profilu bezpieczeństwa, niosącymi najwięcej korzyści dla pacjentów z nieparafilicznymi zaburzeniami wydają się SSRI. Nie zaleca się leków o działaniu antyandrogenowym (LHRH) z powodu działań niepożądanych,

\section{Introduction}

Sexual experiences significantly increase the level of life satisfaction; they are an important source of mental pleasure and their fulfilment is usually associated with experiencing emotional and physical closeness. The perception and assessment of certain types of sexual behaviour have a significant impact on the assessment of their normativeness. An important function is currently performed by the media, which serve as an element of social engineering as well as a control tool. They stimulate the development of culture, shape the imagination of the audience, influence their views and attitudes, and thus increasingly participate in the liberalisation of the human sexual sphere (Gola, 2008). It is worth noting the increasing commercialisation of the human sexual sphere, in which satisfying sexual needs becomes another element of consumerism. Sexual stimuli are increasingly being used directly or indirectly in business to increase profits, as evidenced by the growing number of sex shops, erotic magazines and the huge illegal supply of pornographic content (Czajkowski and Banaszak, 2008). The widespread availability of erotic content stimulates and at the same time facilitates the release of sexual tension, often independent of the emotional relationship with the partner. It happens that encountering erotic content occurs too early in life, which has a significant impact on further psychosexual development, thus shaping the way the tension is released.

The diagnosis of sex addiction (sexaholism) is a source of many methodological difficulties. The term is not medically defined and there are still no agreed criteria for its diagnosis. It is associated with sexual immaturity, impairment of the mechanisms of sexual inhibition, poza przypadkami przebiegającymi z bardzo nasilonymi objawami. Obiecujące wyniki osiągnęli badacze podczas próby z naltreksonem, jednak badanie nie spełniało norm metodologicznych. Inne leki stosowane w terapii kompulsywnych zachowań seksualnych mają znaczenie pomocnicze, mogą być wykorzystywane szczególnie przy współwystępowaniu innych schorzeń psychiatrycznych. Wnioski. Najlepsze efekty w terapii kompulsywnych zachowań seksualnych daje połączenie psychoterapii z lekami z grupy SSRI. Istnieje bardzo mało prawidłowych metodologicznie badań, zazwyczaj są one przeprowadzane na zbyt małej grupie i nie wykorzystują narzędzi, które umożliwiałyby porównywanie różnych metod terapeutycznych. Należy kontynuować badania nad farmakoterapią hiperseksualności nieparafilicznej, szczególnie w zakresie leków mogących wpływać na „mechanizm obsesyjno-kompulsywny".

disruption of bonds - not only from the perspective of the abnormal intensification of sexual desire that took place in the past. The broadening of the spectrum of possible causes of the disorder gives greater opportunities to psychotherapists who, by helping people with excessive sexual behaviour, look for both individualised and effective methods. At present, the term "compulsive sexual behaviour" is preferred to "sexaholism" when referring to the phenomenon of addiction to sex. There are ongoing discussions on whether pathological hypersexuality can be included in the spectrum of behavioural addiction.

Compulsive sexual behaviour is characterised by the intensity of needs and sexual behaviour, which results in several negative psychological, social and somatic consequences. In addition to the intensification of sexual life in people affected by the addiction, it is also possible to observe a disturbance of impulse control, frequent search for new sexual partners, pathological striving to confirm sexual fitness as well as sexual behaviour in unfavourable, extremely risky situations (Lew-Starowicz, 1991). Carnes et al., based on research and clinical practice, indicate that the most common symptoms include loss of control over sexual behaviour and the resulting severe consequences as well as lack of ability to stop sexual behaviour, repetition of self-destructive behaviour and risky situations. Patients use sexual fantasies and erotic sensations as their main coping strategy and experience a growing demand for sensations (increasing tolerance) and non-specific withdrawal symptoms at times when they refrain from sexual activity. They also spend too much time on finding new partners, neglecting professional, family and hobby matters (Carnes et al., 2001).

Hypersexual behaviour, in addition to sexual contacts with another person, also includes autoerotic behaviour 
(usually connected with watching pornography) and cybersex (virtual sex encounter in which two or more people connected remotely via computer network send each other sexually explicit messages/content) (de Alarcón et al., 2019).

As mentioned, defining hypersexuality is very difficult. World Health Organisation (WHO) continues to point out that further work on the official introduction of this term is advisable. At present, there is no nosologic unit defined as sex addiction or sexaholism, but the current International Statistical Classification of Diseases and Related Health Problems (ICD-11) includes the term "compulsive sexual behaviour disorder" (ICD-11, 2020). The heterogeneity of the concept makes it difficult to categorise sexaholism unambiguously. The international classification of ICD-10 diseases included excessive sexual activity under the diagnosis of "excessive sexual drive," which belongs to the category of "sexual dysfunctions" (ICD-10, 2008). A newer edition, the ICD-11, includes pathological hypersexualism in the category of "impulse control disorders" as "compulsive sexual behaviour". Including sexaholism in this group of disorders indicates that the lack of impulse control is an important element of the pathopsychology of this disorder. The matter of terminology was also very ardent in the American Psychiatric Association DSM. In the latest, fifth edition issued in 2013 (DSM-5), sexual dysfunction issues are included in the Sexual Disorder Not Otherwise Specified category. It was previously excluded in the fourth edition (DSM-IV) just after it appeared in the revised third edition (DSM-III). The authors of this article decided to use the terms "pathological hypersexuality" and "compulsive sexual behaviour" interchangeably.

The lack of definition of adverse sexual behaviour and the non-existence of a consistent conceptualisation of the problem, as well as the related diagnostic obstacles, have led to a shortage of current epidemiological studies on large trial samples. Compulsive sexual behaviour may affect 3-6\% of the population, and the discrepancies are mainly due to the diversity of the study groups, as well as diagnostic tests (Carnes et al., 2001; Odlaug et al., 2013; Rosenberg et al., 2014). Some studies show disproportions between groups of men and women, concerning both the number and forms of undertaken pathological activities. Women are more likely to experience seductive behaviour and "addiction to love," while men experience compulsive masturbation and paraphilia (Kuzma et al., 2008; Bancroft and Vukadinovic, 2004). Very interesting are the results concerning the epidemiology of sexual disorders in specific groups, especially among sex offenders. In 2008, Marshall et al. conducted a study in which they estimated the prevalence of sexual dependence at $35-43 \%$ in the study group, compared with $12-15 \%$ in the control group (Marshall et al., 2008).

Over the years of research into the phenomenon of pathological hypersexuality, numerous psychopathological mechanisms explaining its nature have been proposed and various authors have described them with different terms. Quadland called it compulsive sexual behaviour (Quadland, 1985), Barth and Kinder called it sexual impulsivity (Barth and Kinder, 1987), Schwartz described it as an aspect of post-traumatic stress disorder (Schwartz, 1992) and Coleman as a variant of obsessive-compulsive disorder (Coleman, 1990).

The main conceptualisations of the problem of compulsive sexual behaviour include a model of sexual drive dysregulation in which fantasies, desires and activities are excessive and maladaptive (Kafka, 2010), an impulsive-compulsive model emphasising deficits in the area of delayed gratification and the compulsion to repeat the behaviour to release tension (Kuzma and Black, 2008), a model of addiction to sexual activity (Rosenberg et al., 2014 ) and the $A B C$ integrative model (affective dysregulation, behavioural addiction, and cognitive dyscontrol), which covers the problem of cognitive and emotional control and addictive behaviour (Stain, 2008).

Pathological hypersexuality began to be seen as an addiction along with the introduction of the concept of behavioural addiction, which made it possible to extend the concept of addiction beyond substance abuse; at the same time, the characteristics were based on the criteria relating to these addictions. Like substance addicts, sexaholics often exhibit traits of tolerance and withdrawal syndrome (Schneider and Irons, 2001). They are also characterised by ruminations, feelings of guilt and regret at the thought of limiting sexual activity and difficulties in controlling their frequency (Garcia and Thibaut, 2010). They may maintain a pattern of excessive engagement in sexual behaviour despite the negative consequences for their own health, family life, marital and legal problems (Kor et al., 2013). In the past, sexaholism was considered an addiction based on empirical and clinical data (Garcia and Thibaut, 2010). Currently, there are neurobiological indications that the pathophysiological mechanisms behind compulsive sexual behaviour are similar to substance addiction (Voon et al., 2014). The results of neuroimaging studies and the common routes of neurotransmission speak for classifying compulsive sexual behaviour as an addiction. However, such data is insufficient to make an unquestionable classification and further studies on the specific pathophysiogenesis of these disorders are necessary for a comprehensive understanding of their characteristics (Kraus et al., 2016).

\section{Materials and methods}

A review of available literature in Polish and English on compulsive sexual disorder pharmacotherapy has been conducted. The PubMed resource based on the Medline database was used as a search tool. The following search terms were used in English: non-paraphilic sexual 
disorders, sexual addiction, hypersexuality, sexual addiction, SSRI, naltrexone, neuroleptics, LHRH, antiandrogens, sexual compulsion.

\section{Pharmacological treatments}

The problem with effective therapy for people suffering from compulsive sexual disorders results from many factors. People addicted to this type of activity often deny the existence of the problem and do not seek help from therapists or psychiatrists. Among those who decide to receive treatment, as much as $70 \%$ are not convinced of the validity of their decision (Reid, 2007). Another problem we encounter is the multitude of mechanisms leading to compulsive sexual behaviour and the fact that pathological hypersexuality can accompany or result from many other mental illnesses. It seems that pharmacological treatment should be dependent on the pathogenesis of the disorder in the individual, in particular, whether hypersexuality results from increased sex drive or from impulse control disorders. Unfortunately, the literature contains very little data on the pharmacological treatment of compulsive sexual behaviour. There are articles available concerning mainly people with disorders from the paraphilia group, in whom the desired effect is total inhibition of sexual activity. Patients with non-paraphilic hypersexuality are expected to stabilise their needs at a level acceptable to the patient, rather than completely inhibit their sexual needs.

\section{Antidepressants}

Currently, the most promising treatment for compulsive sexual behaviour seems to be SSRI drugs (selective serotonin reuptake inhibitor). Such drugs are widely used in many mental disorders. Their use is at risk of side effects, which ironically turns out to have a therapeutic effect in the treatment of sexual disorders. SSRI drugs have a negative impact on the sexual sphere of the human being, causing a decrease in libido, difficulty in reaching orgasm or anorgasmia, delayed ejaculation, inability to ejaculate, impotence or decrease in overall sexual satisfaction. The influence on serotonin receptors, decrease in dopamine concentration and increase in prolactin concentration are responsible for lowering sexual function. In addition, SSRI drugs have $\beta$-adrenergic, anticholinergic effect and reduce NO concentration (Balloon et al., 1993). An additional postulated effect of SSRI is the reduction of the symptoms of obsession and compulsion, which can have an additional positive therapeutic effect. The strongest side effects in the sexual sphere were observed in the use of paroxetine (Montejo-Gonzales et al., 1997). There are also reports indicating a decrease in testosterone levels during fluoxetine therapy (Aguirre, 1999).

The most commonly proposed dosing regimen for fluoxetine is to start the therapy with $20 \mathrm{mg}$ per day and gradually increase to $80 \mathrm{mg}$ per day. In the available studies, the effectiveness of fluoxetine ranged from 0 to $90 \%$. However, it should be stressed that the measurement of drug efficacy was conducted on different groups of patients with different clinical scales (Guay, 2009). In addition, there are studies showing the beneficial effects of combining SSRI drugs with psychostimulants, such as fluoxetine and methylphenidate. This combination results in a reduction in the number of excessive sexual behaviour in people with pathological hypersexuality and a reduction in the time spent on these activities (Kafka and Hennen, 2000). The use of such a combination of drugs seems to be particularly appropriate in patients with hypersexuality with accompanying ADHD (Habrat et al., 2012).

\section{Naltrexone}

Naltrexone is another drug that can be effective in treating compulsive sexual behaviour. It is a long-acting opioid derivative that blocks the access of endogenous opioids to their receptors in the central nervous system. Naltrexone does not cause mental or physical addiction and does not build up a tolerance. It is used to reduce harm in the treatment of alcohol use disorder as a drug to support abstinence and reduce the need to drink alcohol. However, the literature lacks large clinical studies on the use of naltrexone in the treatment of these disorders. So far, only a few such studies have been conducted with persons with paraphilic disorders - the results seem promising (Ryback, 2004).

\section{Anti-psychotics}

Neuroleptics, both classical and atypical, have also been studied for their potential efficacy in treating compulsive sexual behaviour. These studies did not confirm a higher efficacy of drugs compared to placebo (Zbytowsky, 1993). Moreover, there are many reports of the occurrence of hypersexuality as an adverse effect of neuroleptics, especially aripiprazole (Reddy et al., 2018). A similar effect is sometimes observed in patients treated for Parkinson's disease taking drugs increasing dopamine levels in CNS (Lopez et al., 2017).

\section{Drugs affecting the hormonal balance}

\section{- LHRH agonists}

Other drugs used to treat sexual disorders are substances that block the secretion of sex hormones. Luteinizing hormone-releasing hormone (LHRH) agonists such as leuprorelin and triptorelin are mainly used in this indication. Their effect consists in inhibiting the secretion of FSH and LH, which in turn reduces the concentration of sex hormones. There has been a lot of research on the use of these drugs in a group of patients with disorders from the paraphilia group, including those with a diagnosis of paedophilia, rapists and other sexual offenders. These drugs can be administered in the form of depot 
injections even with the intervals of 180 days, which makes it easier for patients to continue the treatment. Some of these drugs were also used for the so-called chemical castration. In addition to the obvious effect on sexual activity, these drugs adversely alter the bone structure, causing a reduction in bone density. However, such effects can be counteracted by supplementation with vitamin D3, calcium or small doses of androgens. The efficacy of gonadotropin-releasing hormone agonist therapy is high. In a study carried out on a group of 12 patients with various disorders from the paraphilia group, all of them reported a decrease in sexual arousal, number of sexual fantasies, inclination to exhibitionism or masturbation.

\section{- Medroxyprogesterone (MPA)}

Medroxyprogesterone is the first drug with a clinically proven effect of lowering libido in people with non-paraphilic sexual disorders and sex offenders. MPA is a progesterone derivative that reduces testosterone alpha-reductase concentration in the liver, resulting in a reduction of testosterone concentrations in plasma and tissues. It is not a typical anti-androgen because it does not bind with androgen receptors. The research has shown a significant impact on the reduction of sexual drive, the occurrence of sexual fantasies, undertaking sexual activity and a decrease in sensitivity to erotic stimuli. The drug can be administered by two routes of administration. In the form of intramuscular injection (a particularly useful form in patients who do not cooperate in therapy) and orally. In Poland, medroxyprogesterone is registered under the name Depo-Provera as a contraceptive for women in the form of intramuscular injections (Codispoti, 2008).

\section{- Cyproterone}

It is a synthetic derivative of progesterone with gestagenic, anti-androgenic and anti-gonadotropic effects. The mechanism of action of this drug is based on competitive binding with testosterone and dihydrotestosterone receptors. It is a drug used in men with a paraphilic type of sexual disorders. Efficacy has been confirmed in many clinical trials (Lippi and van Staden, 2017). Cyproterone lowers libido, reduces the incidence of sexual fantasies and generally reduces the number of sexual acts (Codispoti, 2008). An oral preparation, Androcur, in a dose of 50 $\mathrm{mg}$, is available in Poland. The preparation is registered to suppress sex drive in men with sexual deviations. Initially a dose of $50 \mathrm{mg}$ twice a day should be used. If necessary, the dose can be increased to $100 \mathrm{mg}$ twice a day. The lowest effective dose of the drug should be used.

Despite the undoubted efficacy of these drugs, their use remains ethically questionable and should only be considered in patients with severe symptoms (Krueger and Kaplan, 2001). There is a lack of methodologically correct research on the use of hormonal treatment in patients suffering from non-paraphilic disorders, including compulsive sexual behaviour.

\section{Beta-blockers}

During the analysis of available literature, case studies on the use of propranolol in the treatment of people suffering from pathological hypersexuality were found. The first case concerned the occurrence of the above-mentioned phenomenon in a minor suffering from autism spectrum disorder. The authors of the study used propranolol in their patient at a dose of $10 \mathrm{mg}$ per day, achieving complete regression of symptoms (Deepmala and Agraval, 2014). Another example of effective use of propranolol in the therapy of compulsive sexual behaviour was the case of a 9-year-old girl with the shaken baby syndrome (SBS), whose hypersexuality was accompanied by general hyperactivity. She began propranolol treatment, starting from a dose of $10 \mathrm{mg}$ a day, which was gradually increased to $40 \mathrm{mg}$ a day. Significant improvements in both hypersexuality and hyperactivity have been achieved. After discontinuation of propranolol (patient's decision), the problem of hypersexuality returned (Schmidt and Schneider, 2000). The use of propranolol can bring many benefits to patients with minimal side effects, but so far there are no data on its use among adults.

\section{Nonpharmacological treatments}

Psychotherapy is an important element of the treatment of people with compulsive sexual behaviour. People struggling with sexaholism, even though they are aware of the consequences of their actions, are usually unable to control their compulsion. Sexual behaviour can be destructive, causing marital and family problems, contributing to difficulties in work life and leading to risky behaviour. Regardless of the cause of sexual disorder and its type, non-pharmacological therapy is based on methods used in chemical addiction. In addition to motivational interviewing, the most effective and common are group or individual cognitive-behavioural therapy and self-help groups that draw on the 12-step method. In recent years, however, few studies have been conducted to assess the efficacy of various forms of psychotherapy for sexual disorders. In 2010, Hardy et al., using psycho-educational intervention, confirmed a decrease in the intensity of symptoms in the examined men (Hardy et al., 2010). Good results were also obtained by Crosby and Twohig in 2016, using ACT (Acceptance and Commitment Therapy) to treat the compulsive use of pornography (Crosby and Twohig, 2016 and Klontz (in 2005), who observed participants in a group treatment programme for six months, using various psychotherapeutic approaches (Klontz et al., 2005).

\section{Discussion}

Most of the referenced studies on the efficacy of pharmacotherapy in the treatment of compulsive sexual 
behaviour have many methodological defects. Most often these studies are conducted on small or very small groups of patients, rarely exceeding 30 people. These groups are most often not homogeneous, i.e. in one study, patients are, for example, those suffering from a disorder from the paraphilia group, such as paedophilia, and "non-paraphilic" patients, who are addicted to e.g. cybersex. The study groups were often composed of persons serving prison sentences for sexual offences or patients of psychiatric wards. In such a situation, subjects may dissimulate their symptoms or simulate other mental disorders due to fear of legal or personal consequences. Another aspect that makes it difficult to analyse the efficacy or safety of given pharmacological methods is the lack of standard tools used to assess their efficacy. Many researchers, therefore, use their own questionnaires based on the subjective assessment of the patient. It is worth noting that currently none of the drugs for the treatment of pathological hypersexuality are registered for the treatment of compulsive sexual disorders. All the therapies specified by the authors may only be used off-label. This involves many difficulties, such as a higher cost of treatment for the patient.

\section{Conclusions}

None of the drugs used in the pharmacotherapy of compulsive sexual disorder is registered in this indication, so their use has the status of a medical experiment of which the patient should be informed. At present, it seems that the best course of action for the patient is cognitive-behavioural psychotherapy with pharmacological support in the form of SSRI drugs. Other drugs have been studied mainly in patients with paraphilias and there is a lack of data on their use to treat compulsive sexual behaviour. It should be remembered that hypersexuality may be a symptom of another mental or somatic disease and the therapy should start with the correct diagnosis and treatment of the primary disease first.

\section{Wstęp}

Przeżycia seksualne istotnie zwiększają poziom satysfakcji z życia, są ważnym źródłem przyjemności psychicznej, a ich realizowanie powiązane jest zazwyczaj z doświadczaniem emocjonalnej i fizycznej bliskości. Sposób postrzegania i ocena określonych typów zachowań seksualnych wpływa znacząco na ocenę ich normatywności. Ważną funkcję pełnią obecnie media, będące elementem inżynierii społecznej, a także narzędziem kontroli. Stymulują one rozwój kultury, kształtują wyobraźnię odbiorców, wpływają na ich poglądy i postawę, i tym samym coraz częściej uczestniczą w liberalizacji sfery seksualnej człowieka (Gola, 2008). Warto zwrócić uwagę na nasilającą się komercjalizację sfery seksualnej człowieka, w której zaspokojenie potrzeb seksualnych staje się kolejnym elementem konsumpcjonizmu. Coraz częściej bezpośrednio lub pośrednio wykorzystuje się bodźce seksualne w biznesie w celu zwiększenia zysków - czego przykładem jest rosnąca ilość seks-sklepów, pism erotycznych oraz ogromna nielegalna podaż treści pornograficznych (Czajkowski i Banaszak, 2008). Powszechna dostępność treści erotycznych pobudza i jednocześnie ułatwia rozładowanie napięcia seksualnego, często niezależnego od relacji emocjonalnej z drugim człowiekiem. Zdarza się, że kontakt z treściami erotycznymi występuje zbyt wcześnie w czasie życia, co ma znaczący wpływ na dalszy rozwój psychoseksualny oraz kształtowanie sposobu rozładowywania napięcia człowieka.

Rozpoznanie uzależnienia od seksu (seksoholizmu) przysparza wielu trudności metodologicznych. Termin

nie jest zdefiniowany medycznie i wciąż nie ma uzgodnionych kryteriów jego rozpoznawania. Wiąże się go z niedojrzałością seksualną, upośledzeniem mechanizmów hamowania seksualnego, zaburzeniem więzi, nie tylko z perspektywy nieprawidłowego nasilenia pożądania seksualnego, które miało miejsce w przeszłości. Poszerzenie spektrum możliwych przyczyn zaburzenia daje większe możliwości psychoterapeutom, którzy pomagając osobom uwikłanym w nadmiarowe zachowania seksualne, szukają metod zarówno zindywidualizowanych, jak i skutecznych. Obecnie wobec zjawiska uzależnienia od seksu preferuje się termin „kompulsywne zachowania seksualne” zamiast „seksoholizm”. Ciągle toczą się dyskusje na temat tego, czy patologiczną hiperseksualność możemy zaliczyć do spektrum uzależnień behawioralnych.

Kompulsywne zachowania seksualne charakteryzują się nasileniem potrzeb oraz zachowań seksualnych, czego skutkiem jest szereg negatywnych konsekwencji psychicznych, społecznych i somatycznych. Oprócz intensyfikacji życia seksualnego u osób dotkniętych uzależnieniem można również zauważyć zakłócenie kontroli impulsów, częste poszukiwanie nowych partnerów seksualnych, patologiczne dążenie do potwierdzenia sprawności seksualnej, a także do zachowań seksualnych w niesprzyjających, skrajnie ryzykownych sytuacjach (Lew-Starowicz, 1991). Carnes i wsp. na podstawie badań i praktyki klinicznej wskazują, że najczęściej występującymi objawami są: utrata kontroli nad zachowaniami seksualnymi i wynikające z tego dotkliwe konsekwencje, a także brak zdolności do zaprzestania zachowań 
seksualnych, powtarzanie autodestrukcyjnych zachowań i ryzykownych sytuacji. Pacjenci jako główną strategię radzenia sobie w życiu stosują fantazje seksualne i doznania erotyczne, i doświadczają rosnącego zapotrzebowania na doznania (rośnie tolerancja) oraz mają niespecyficzne objawy abstynencyjne w okresach, kiedy powstrzymują się od aktywności seksualnej. Poświęcają oni również nadmiernie dużo czasu na zdobywanie nowych partnerów, zaniedbując przy tym sprawy zawodowe, rodzinne i hobby (Carnes i wsp., 2001).

Zachowania hiperseksualne, oprócz czynności seksualnych z inną osobą, obejmują również zachowania autoerotyczne (najczęściej powiązane z oglądaniem pornografii) oraz cyberseks (zachowania seksualne w sieci internetowej) (de Alarcón i wsp., 2019).

Jak wspomniano, zdefiniowanie hiperseksualności jest bardzo trudne, a Światowa Organizacja Zdrowia (WHO) wciąż zaznacza, że wskazane są dalsze prace nad oficjalnym wprowadzeniem tego terminu. Obecnie nie istnieje jednostka nozologiczna sprecyzowana jako uzależnienie od seksu czy seksoholizm, natomiast w aktualnej Międzynarodowej Klasyfikacji Chorób i Problemów Zdrowotnych ICD-11 (ang. International Statistical Classification od Diseases and Related Health Problems) figuruje określenie „zaburzenie kompulsywnych zachowań seksualnych" (ICD-11, 2020). Niejednorodność koncepcji utrudnia jednoznaczną kategoryzację seksoholizmu. Międzynarodowa klasyfikacja chorób ICD-10 ujmowała nadmierne czynności seksualne pod rozpoznaniem „nadmierny popęd seksualny” należący do kategorii „dysfunkcje seksualne" (ICD-10, 2008). Nowsze wydanie, ICD-11, włącza hiperseksualizm patologiczny do kategorii „zaburzenia kontroli impulsów” jako „kompulsywne zachowania seksualne". Przeniesienie seksoholizmu do tej grupy zaburzeń wskazuje, iż brak kontroli impulsów jest istotnym elementem patopsychologii tego zaburzenia. Sytuacja terminologii była burzliwa również w opracowanym przez American Psychiatric Association DSM. W najnowszym, piątym, wydaniu z 2013 roku (DSM-5) problematykę związaną z zaburzeniami funkcji seksualnych umieszczono w kategorii zaburzeń seksualnych niesklasyfikowanych nigdzie indziej (ang. Sexual Disorder Not Otherwise Specified). Wcześniej została ona wykluczona w wydaniu czwartym (DSM-IV) tuż po tym, jak pojawiła się w poprawionym wydaniu trzecim (DSM-III). Autorzy niniejszego artykułu zdecydowali się używać terminów „hiperseksualność patologiczna” oraz „kompulsywne zachowania seksualne" zamiennie.

Brak definicji szkodliwych zachowań seksualnych i nieistnienie spójnej konceptualizacji problemu, a także związane z tym przeszkody diagnostyczne doprowadziły do niedoboru aktualnych badań epidemiologicznych na dużych próbach. Nałogowe zachowania seksualne mogą dotyczyć 3-6\% populacji, a rozbieżności wynikają głównie ze zróżnicowania grup badanych, a także badań diagnostycznych (Carnes i wsp., 2001; Odlaug i wsp.,
2013; Rosenberg i wsp., 2014). Część badań wykazuje dysproporcje pomiędzy grupami mężczyzn i kobiet, dotyczące zarówno liczby, jak i form podejmowanych patologicznych aktywności. Kobiety częściej borykają się z zachowaniami uwodzącymi i „uzależnieniem od miłości", natomiast mężczyźni doświadczają problemu z kompulsywną masturbacją i parafiliami (Kuzma i wsp., 2008; Bancroft i Vukadinovic, 2004). Bardzo ciekawe są wyniki dotyczące epidemiologii zaburzeń seksualnych w grupach specyficznych - szczególnie wśród sprawców przestępstw seksualnych. W 2008 roku Marshall i wsp. przeprowadzili badanie, w którym oszacowali występowanie uzależnienia seksualnego na poziomie $35-43 \%$ w grupie badanej, w porównaniu z $12-15 \%$ w grupie kontrolnej (Marshall i wsp., 2008).

Na przestrzeni lat badań zjawiska patologicznej hiperseksualności zaproponowano liczne mechanizmy psychopatologiczne tłumaczące jego naturę, a różni autorzy opisywali je odmiennymi terminami. Quadland nazwał je kompulsywnym zachowaniem seksualnym (Quadland, 1985), Barth i Kinder impulsywnością seksualną (Barth i Kinder, 1987), Schwartz określił je jako aspekt zespołu stresu pourazowego (Schwartz, 1992), a Coleman jako wariant zaburzenia obsesyjno-kompulsywnego (Coleman, 1990).

Główne konceptualizacje problemu kompulsywnych zachowań seksualnych obejmują: model dysregulacji popędu seksualnego, w którym fantazje, pragnienia i aktywności są nadmierne i dezadaptacyjne (Kafka, 2010), model impulsywno-kompulsywny, podkreślający deficyty w obszarze odraczania nagrody i przymus powtarzania zachowania w celu redukcji napięcia (Kuzma i Black, 2008), model uzależnienia od aktywności seksualnej (Rosenberg i wsp., 2014) oraz integracyjny model ABC (ang. affective dysregulation, behavioral addiction, and cognitive dyscontrol), który obejmuje problem kontroli poznawczej, emocjonalnej oraz zachowania uzależnienieniowe (Stain, 2008).

Hiperseksualność patologiczną zaczęto postrzegać jako uzależnienie wraz z wprowadzeniem pojęcia uzależnień behawioralnych, co umożliwiło rozszerzenie koncepcji uzależnienia poza nałogowe używanie substancji; jednocześnie charakterystykę oparto na kryteriach dotyczących tychże nałogów. Podobnie jak osoby uzależnione od substancji, seksoholicy często przejawiają cechy tolerancji oraz zespołu odstawiennego (Schneider i Irons, 2001). Cechują ich również ruminacje, poczucie winy i żalu na myśl o redukcji podejmowanych aktywności seksualnych oraz trudności w kontroli ich częstotliwości (Garcia, Thibaut, 2010). Mogą oni utrzymywać wzorzec nadmiernego angażowania się w zachowania seksualne pomimo negatywnych konsekwencji dla własnego zdrowia, życia rodzinnego, problemów małżeńskich i prawnych (Kor i wsp., 2013). Dawniej uznawano seksoholizm za uzależnienie na podstawie danych empirycznych oraz klinicznych (Garcia i Thibaut, 2010). Obecnie pojawiają 
się przesłanki neurobiologiczne przybliżające mechanizmy patofizjologiczne stojące za kompulsywnymi zachowaniami seksualnymi, wskazujące na ich podobieństwo do uzależnień od substancji (Voon i wsp., 2014). Wyniki badań neuroobrazowych oraz wspólne szlaki neurotransmisji przemawiają za zaliczaniem kompulsywnych zachowań seksualnych do uzależnień. Dane te są jednak niewystarczające, by dokonać niebudzącej wątpliwości klasyfikacji, a dalsze badania dotyczące szczegółowej patoetiogenezy tych zaburzeń są niezbędne do całościowego zrozumienia ich charakterystyki (Kraus i wsp., 2016).

\section{Materiały i metody}

Dokonano przeglądu dostępnego piśmiennictwa w języku polskim $\mathrm{i}$ angielskim na temat farmakoterapii kompulsywnych zaburzeń seksualnych. Jako narzędzi do wyszukiwania danych użyto przeglądarki PubMed bazującej na zasobach bazy Medline. Użyto następujących haseł wyszukiwania w języku angielskim: nonparaphilic sexual disorders, sexual addiction, hypersexuality, sexual addiction, SSRI, naltrexon, neuroleptics, LHRH, antiandrogens, sexual compulsivism.

\section{Farmakologiczne metody leczenia}

Problem ze skuteczną terapią osób cierpiących na kompulsywne zaburzenia seksualne wynika z wielu czynników. Osoby uzależnione od tego rodzaju aktywności często negują swój problem i nie szukają pomocy terapeutów czy psychiatrów. Wśród osób, które zdecydują się na leczenie, aż 70\% nie jest przekonana o słuszności swojej decyzji (Reid, 2007). Kolejnym problemem, który napotykamy, jest mnogość mechanizmów prowadzących do kompulsywnych zachowań seksualnych oraz fakt, że hiperseksualność patologiczna może towarzyszyć wielu innym chorobom psychicznym, czy też z nich wynikać. Wydaje się, że leczenie farmakologiczne powinno być uzależnione od patogenezy zaburzenia u danej osoby, a w szczególności od tego, czy hiperseksualność wynika ze zwiększonego popędu płciowego, czy jest wynikiem zaburzeń kontroli impulsów. Niestety w literaturze znajduje się bardzo mało danych dotyczących farmakologicznego leczenia kompulsywnych zachowań seksualnych. Dostępne są artykuły dotyczące głównie osób z zaburzeniami z grupy parafilii, u których pożądanym efektem jest właściwie całkowite zahamowanie aktywności seksualnej. U pacjentów z hiperseksualnością nieparafiliczną oczekuje się stabilizacji potrzeb na akceptowalnym przez pacjenta poziomie, a nie całkowitego wygaszenia potrzeb seksualnych.

\section{Leki przeciwdepresyjne}

Obecnie najbardziej obiecujące w leczeniu kompulsywnych zachowań seksualnych wydają się leki z grupy SSRI (ang. selective serotonin reuptake inhibitor). Leki z tej grupy stosuje się szeroko w wielu zaburzeniach psychicznych. Ich stosowanie jest obarczone ryzykiem wystąpienia działań niepożądanych, które paradoksalnie okazują się działaniami terapeutycznymi w terapii zaburzeń seksualnych. Leki SSRI wpływają negatywnie na sferę seksualną człowieka, powodując zmniejszenie libido, trudność w uzyskaniu orgazmu lub anorgazmię, opóźniony wytrysk, niezdolność do wytrysku, impotencję czy spadek ogólnej satysfakcji seksualnej. Za obniżenie funkcji seksualnych odpowiada wpływ na receptory serotoninowe, spadek stężenia dopaminy oraz wzrost stężenia prolaktyny. Dodatkowo leki z grupy SSRI mają działanie b-adrenergiczne, antycholinergiczne oraz zmniejszają stężenie NO (Balon i wsp., 1993). Dodatkowym postulowanym efektem działania SSRI jest zmniejszenie objawów obsesji i kompulsji, co może przynieść dodatkowy pozytywny efekt terapeutyczny. Najsilniejsze działania uboczne w sferze seksualnej zaobserwowano podczas używania paroksetyny (Montejo-Gonzales i wsp., 1997). Istnieją także doniesienia wskazujące na spadek stężenia testosteronu podczas terapii fluoksetyną (Aguirre, 1999).

Najczęściej proponowanym schematem dawkowania fluoksetyny jest rozpoczynanie terapii od dawki $20 \mathrm{mg}$ na dobę i stopniowe zwiększanie do $80 \mathrm{mg}$ na dobę. W dostępnych badaniach skuteczność działania fluoksetyny wahała się od 0 do $90 \%$. Należy jednak podkreślić, że pomiar skuteczności leku prowadzony był na różnych grupach pacjentów z wykrzystaniem różnych skal klinicznych (Guay, 2009). Istnieją ponadto badania dowodzące korzystnego działania połączenia leków z grupy SSRI z lekami psychostymulującymi, jak np. fluoksetyna i metylofenidat. Połączenie to powoduje u osób z patologiczną hiperseksualnością zmniejszenie liczby nadmiernych zachowań seksualnych oraz skrócenie czasu spędzanego na tych aktywnościach (Kafka i Hennen, 2000). Zastosowanie takiej kombinacji leków wydaje się szczególnie zasadne wśród pacjentów z hiperseksualnością z towarzyszącym ADHD (Habrat i wsp., 2012).

\section{Naltrekson}

Kolejnym lekiem mogącym mieć skuteczność w terapii kompulsywnych zachowań seksualnych jest naltrekson. Jest to długodziałająca pochodna opioidowa, która blokuje dostęp endogennym opioidom do ich receptorów w ośrodkowym układzie nerwowym. Naltrekson nie powoduje uzależnienia psychicznego ani fizycznego oraz nie wywołuje zjawiska tolerancji. Jest stosowany do redukcji szkód w terapii choroby alkoholowej jako lek wspomagający abstynencję i zmniejszający potrzebę sięgnięcia po alkohol. W literaturze brakuje jednak dużych badań klinicznych dotyczących stosowania naltreksonu w terapii omawianych zaburzeń. Dotychczas przeprowadzono tylko kilka takich badań u osób z zaburzeniami parafilicznymi - wyniki wydają się obiecujące (Ryback, 2004). 


\section{Leki przeciwpsychotyczne}

Neuroleptyki, zarówno klasyczne, jak i atypowe, były również badane pod kątem potencjalnej skuteczności w leczeniu kompulsywnych zachowań seksualnych. Badania te nie potwierdziły wyższej skuteczności leków w porównaniu z placebo (Zbytowsky, 1993). Co więcej, istnieje wiele doniesień dotyczących występowania hiperseksualności jako działania niepożądanego neuroleptyków, szczególnie aripiprazolu (Reddy i wsp., 2018). Podobny efekt obserwuje się niekiedy u chorych leczonych z powodu choroby Parkinsona przyjmujących leki zwiększające poziom dopaminy w OUN (Lopez i wsp., 2017).

\section{Leki wpływające na gospodarkę hormonalnq}

\section{- Agoniści LHRH}

Kolejnymi lekami wykorzystywanym do terapii zaburzeń seksualnych są substancje blokujące wydzielanie hormonów płciowych. W tym wskazaniu stosuje się głównie agonistów LHRH (ang. Luteinizing Hormone-Releasing Hormone Agonists), jak leuprorelina czy triptorelina. Ich działanie polega na hamowaniu wydzielania FSH i LH, co w konsekwencji powoduje obniżenie stężenia hormonów płciowych. Istnieje sporo badań dotyczących stosowania tych leków w grupie pacjentów cierpiących na zaburzenia z grupy parafilii, w tym u osób z rozpoznaniem pedofilii, sprawców gwałtów oraz innych przestępstw na tle seksualnym. Leki te mogą być podawane w formie depot nawet co $180 \mathrm{dni}$, co ułatwia pacjentom wytrwanie w terapii. Część z tych leków wykorzystywana była również do przeprowadzania tzw. chemicznych kastracji. Poza oczywistym wpływem na czynności płciowe leki te niekorzystnie alterują gospodarkę kostną, powodując zmniejszenie gęstości kości. Można jednak przeciwdziałać takim efektom, suplementując witaminę D3, wapń lub podając niewielkie dawki androgenów. Skuteczność terapii agonistami gonadoliberyny jest wysoka. W badaniu przeprowadzonym na grupie 12 pacjentów z różnymi zaburzeniami z grupy parafilli u wszystkich odnotowano spadek pobudzenia seksualnego, ilości fantazji na tle seksualnym, skłonności do ekshibicjonizmu czy masturbacji.

\section{- Medroksyprogesteron (MPA)}

Medroksyprogesteron jest pierwszym lekiem o potwierdzonym w badaniach klinicznych efekcie obniżającym libido u osób z nieparafilicznymi zaburzeniami seksualnymi oraz wśród przestępców seksualnych. MPA jest pochodną progesteronu, która obniża stężenia alfa-reduktazy testosteronu w wątrobie, co powoduje zmniejszenie stężenia testosteronu w osoczu i tkankach. Nie jest typowym antyandrogenem ponieważ nie łączy się z receptorami androgenowymi. Podczas badań wykazano istotny wpływ na zmniejszenie popędu seksualnego, występowanie fantazji seksualnych, podejmowanie aktywności seksualnej czy spadek wrażliwości na bodźce erotyczne. Lek może być podawany dwiema drogami. W postaci iniekcji domięśniowej (postać szczególnie użyteczna u pacjentów niewspółpracujących w terapii) oraz doustnie. W Polsce medroksyprogesteron jest zarejestrownay pod nazwą Depo-Provera jako lek antykoncepcyjny dla kobiet w postaci iniekcji domięśniowych (Codispoti, 2008).

\section{- Cyproteron}

Jest to syntetyczna pochodna progesteronu o działaniu gestagennym, antyandrogenowym i antygonadotropowym. Mechanizm działania tego leku polega na kompetytywnym łączeniu się z receptorami testosteronowymi i dihydrotestosteronowymi. Jest lekiem stosowanym u mężczyzn z parafilicznym typem zaburzeń seksualnych. Skuteczność została potwierdzona w wielu badaniach klinicznych (Lippi i van Staden, 2017). Cyproteron obniża libido, zmniejsza częstość występowania fantazji seksualnych oraz ogólnie zmniejsza ilość podejmowanych aktów seksualnych (Codispoti, 2008). W Polsce dostępny jest preparat doustny Androcur w dawce $50 \mathrm{mg}$. Preparat jest zarejestrowany do tłumienia popędu w dewiacjach seksualnych u mężczyzn. Początkowo powinno się stosować dawkę 50 mg 2 razy na dobę. W razie konieczności można zwiększyć dawkę do 100 mg 2 razy na dobę. Należy stosować najmniejszą skuteczną dawkę leku.

Pomimo niewątpliwej skuteczności tych leków ich stosowanie pozostaje etycznie wątpliwe i powinno być rozważane tylko u pacjentów z bardzo nasilonymi objawami (Krueger i Kaplan, 2001). Brakuje poprawnych metodologicznie badań dotyczących zastosowania leczenia hormonalnego u pacjentów cierpiących na zaburzenia nieparafiliczne, w tym kompulsywne zachowania seksualne.

\section{Betablokery}

Podczas analizy dostępnego piśmiennictwa znaleziono opisy kazuistyczne dotyczące stosowania propranololu w terapii osób cierpiących z powodu patologicznej hiperseksualności. Pierwszy przypadek dotyczył występowania wyżej wymienionego zjawiska u osoby nieletniej, ciepiącej na zaburzenia ze spektrum autyzmu. Autorzy badania stosowali u swojego pacjenta propranolol w dawce $10 \mathrm{mg}$ na dobę, uzyskując całkowite ustąpienie objawów (Deepmala i Agrawal, 2014). Kolejnym przykładem skutecznego zastosowania propranololu w terapii kompulsywnych zachowań seksualnych był przypadek 9-letniej dziewczynki z zespołem dziecka potrząsanego (SBS), u której hiperseksualności towarzyszyła uogólniona nadaktywność. Rozpoczęto u niej terapię propranololem, zaczynając od dawki $10 \mathrm{mg}$ na dobę i stopniowo zwiększając ją do $40 \mathrm{mg}$ na dobę. Uzyskano znaczną poprawę w zakresie zarówno hiperseksualności, jak i nadaktywności. Po odstawieniu propranololu (decyzja pacjentki) problem hiperseksualności powrócił (Schmidt i Schneider, 2000). Zastosowanie propranololu może przynieść chorym wiele korzyści przy minimalnych działaniach ubocznych, jednak jak dotąd brakuje danych dotyczących stosowania go wśród osób dorosłych. 


\section{Pozafarmakologiczne metody leczenia}

Istotnym elementem leczenia osób z kompulsywnymi zachowaniami seksualnymi jest psychoterapia. Osoby zmagające się z seksoholizmem, nawet zdając sobie sprawę z konsekwencji swojego postępowania, zwykle nie potrafią zapanować nad przymusem. Zachowania seksualne bywają destrukcyjne, powodując problemy małżeńskie i rodzinne, przyczyniając się do trudności w życiu zawodowym oraz prowadząc do ryzykownych zachowań. Bez względu na podłoże zaburzenia seksualnego i jego rodzaj, terapia niefarmakologiczna opiera się na metodach stosowanych w uzależnieniach chemicznych. Najskuteczniejsze i najbardziej powszechne, oprócz wywiadu motywującego, są grupowa lub indywidualna terapia poznawczo-behawioralna oraz grupy samopomocy czerpiące z metody 12 kroków. W ostatnich latach przeprowadzono jednak niewiele badań mających na celu ocenę skuteczności różnych form psychoterapii zaburzeń seksualnych. W 2010 roku Hardy i wsp., stosując oddziaływania psychoedukacyjne, potwierdzili zmniejszenie nasilenia objawów u przebadanych mężczyzn (Hardy i wsp., 2010). Dobre wyniki uzyskali również badacze Crosby i Twohig w 2016 roku, stosując terapię ACT (ang. Acceptance and Commitment Therapy) w leczeniu kompulsywnego korzystania z pornografii (Crosby i Twohig, 2016, oraz Klontz (w 2005 roku), który obserwował przez pół roku osoby biorące udział w programie leczenia grupowego, z wykorzystaniem różnych podejść psychoterapeutycznych (Klontz i wsp., 2005).

\section{Dyskusja}

Większość przytoczonych badań dotyczących skuteczności stosowania farmakoterapii w leczeniu kompulsywnych zachowań seksualnych obarczona jest wieloma wadami metodologicznymi. Najczęściej są to badania prowadzone na małych lub bardzo małych grupach pacjentów, rzadko przekraczających 30 osób. Grupy te najczęściej nie są jednorodne, tzn. podczas jednego badania pacjentami są na przykład osoby cierpiące na zaburzenia z grupy parafilii, takie jak pedofilia, oraz pacjenci „nieparafiliczni”, uzależnieni np. od cyberseksu. Grupę badaną często stanowią osoby odbywające karę więzienia za przestępstwa seksualne czy pacjenci oddziałów psychiatrycznych. W takiej sytuacji badani mogą dysymulować objawy lub symulować inne zaburzenia psychiczne z obawy przed konsekwencjami prawnymi lub osobistymi. Kolejnym aspektem utrudniającym analizę skuteczności czy bezpieczeństwa danych metod farmakologicznych jest brak standardowych narzędzi używanych do oceny ich skuteczności. Wielu badaczy stosuje więc własne kwestionariusze oparte na subiektywnej ocenie pacjenta. Warto podkreślić, że obecnie żaden z leków do leczenia patologicznej hiperseksualności nie jest zarejestrowany do leczenia kompulsywnych zaburzeń seksualnych. Wszystkie podane przez autorów terapie mogą być stosowane jedynie off-label. Wiąże się to $\mathrm{z}$ wieloma trudnościami, takimi jak np. większy koszt terapii dla pacjenta.

\section{Wnioski}

Żaden z leków używanych w farmakoterapii kompulsywnych zaburzeń seksualnych nie jest zarejestrowany w tym wskazaniu, stąd ich używanie ma status eksperymentu medycznego, o czym należy poinformować pacjenta. Obecnie wydaje się, że najlepszym postępowaniem dla pacjenta jest stosowanie psychoterapii poznawczo-behawioralnej z farmakologicznym wsparciem w postaci leków z grupy SSRI. Inne leki były badane głównie u pacjentów z parafiliami i brakuje danych dotyczących ich stosowania w leczeniu kompulsywnych zachowań seksualnych. Należy pamiętać, iż hiperseksualność może być objawem innego schorzenia psychicznego bądź somatycznego i terapię powinno się zaczynać od postawienia prawidłowej diagnozy i leczenia w pierwszej kolejności choroby pierwotnej.
Conflict of interest and financial support non declared. / Nie zgłoszono konfliktu interesów oraz dofinansowania.

The work described in this article has been carried out in accordance with The Code of Ethics of the World Medical Association (Declaration of Helsinki) for experiments involving humans, EU Directive 2010/63/EU for animal experiments, and Uniform Requirements for manuscripts submitted to biomedical journals. / Treści przedstawione w artykule są zgodne z zasadami Deklaracji Helsińskiej, dyrektywami EU oraz ujednoliconymi wymaganiami dla czasopism biomedycznych.
Authors' contributions / Wkład autorów: BK, AK, EM, MK - literature review and draft of the article / przegląd piśmiennictwa i draft artykułu; GB, MK - concept of the article, manuscript writing, scientific editing of the work being prepared / koncepcja pracy, pisanie manuskryptu, redakcja naukowa przygotowywanej pracy

\section{References / Piśmiennictwo}

1. Aguirre B. Fluoxetine and compulsive sexual behavior. J Am Acad Child Adolesc Psychiatry 1999; 38: 943. 
2. de Alarcón R, de la Iglesia JI, Casado NM, Montejo AL. Online Porn Addiction: What We Know and What We Don't-A Systematic Review. J Clin Med 2019; 8: 91.

3. Balon R, Yeragani VK, Pohl R, Ramesh C. Sexual dysfunction during antidepressant treatment. J Clin Psychiatry 1993; 54: 209-212.

4. Bancroft J, Vukadinovic Z. Sexual addiction, sexual compulsivity, sexual impulsivity, or what? Toward a theoretical model. J Sex Res 2004; 41: 225-234.

5. Barth RJ, Kinder BN. The mislabeling of sexual impulsivity. J Sex Marital Ther 1987; 13: 15-23.

6. Carnes PJ., Delmonico D., Griffin E., Moriarty J. In the shadows of the net: Breaking free of compulsive online sexual behaviro. Center City, MN: Hazelden Educational Materials 2001.

7. Codispoti VL., Pharmacology of sexually compulsive behavior. Psychiatr Clin North Am. 2008; 31: 671-679.

8. Coleman E., The obsessive-compulsive model for describing compulsive sexual behavior. Am. J. Prev. Psychiatry Neurol 1990; 1: 9-14.

9. Crosby JM, Twohig MP. Acceptance and Commitment Therapy for Problematic Internet Pornography Use: A Randomized Trial. Behav Ther 2016; 47: 355-366.

10. Czajkowski P, Banaszak E. Moralne obrazy. Społeczne i socjologiczne (de)konstrukcje seksualności, Wydawnictwo Uniwersyteckie, Wrocław 2008.

11. Deepmala, Agrawal M. Use of propranolol for hypersexual behavior in an adolescent with autism. Ann Pharmacother 2014; 48: 1385-1388.

12. DSM-5,American Psychiatric Association. Diagnostic and Statistical Manual of Mental Disorders. Arlington: American Psychiatric Association Publishing; 2013.

13. Garcia FD, Thibaut F. Sexual addictions. Am J Drug Alcohol Abuse 2010; 36: 254-260.

14. Gola B. Modele zachowań seksualnych, Wydawnictwo Uniwersytetu Jagiellońskiego, Kraków 2008.

15. Guay DR. Drug treatment of paraphilic and nonparaphilic sexual disorders. Clin Ther 2009; 31: 1-31.

16. Habrat B, Jelonkiewicz I, Lew-Starowicz M, Silczuk A. Dokonanie przeglądu aktualnego stanu światowej wiedzy naukowej dotyczącej uzależnień behawioralnych, w tym hazardu problemowego i patologicznego, Wydawnictwo Instytutu Psychiatrii i Neurologii w Warszawie, Warszawa 2012.

17. Hardy S, Ruchty J, Hull T, Hyde R. A Preliminary Study of an Online Psychoeducational Program for Hypersexuality, Sex Addict Compulsivity 2010; 17: 247-269.

18. ICD-10, World Health Organization, Międzynarodowa Statystyczna Klasyfikacja Chorób i Problemów Zdrowotnych - X rewizja. 2008.

19. ICD-11, World Health Organization, Międzynarodowa Statystyczna Klasyfikacja Chorób i Problemów Zdrowotnych - XI rewizja. 2020.

20. Kafka MP. Hypersexual disorder: a proposed diagnosis for DSM-V. Arch Sex Behav 2010; 39: 377-400.

21. Kafka M, Hennen J. Psychostimulant augmentation during treatment with selective serotonin reuptake inhibitors in men with paraphilias and paraphilia-related disorders: A case series. Journal of Clinical Psychiatry 2000, 61: 664-670.

22. Klontz BT, Garos S, Klontz PT. The effectiveness of brief multimodal experiential therapy in the treatment of sexual addiction. Sex Addict Compulsivity 2005; 12: 275-294.

23. Kor A, Fogel Y, Reid RC, Potenza MN. Should Hypersexual Disorder be Classified as an Addiction? Sex Addict Compulsivity 2013; 20: 1-2.
24. Kraus SW, Voon V, Potenza MN. Should compulsive sexual behavior be considered an addiction? Addiction. 2016 Dec;111(12):2097-2106.

25. Krueger RB, Kaplan MS. Depotleuprollde acetate for treatment of paraphillas: A report of twelve cases. Arch Sex Behav 2001; 30: 409-422.

26. Kuzma JM, Black DW. Epidemiology, prevalence, and natural history of compulsive sexual behavior. Psychiatr Clin North Am 2008; 31: 603-611.

27. Lew-Starowicz Z. Leczenie nerwic seksualnych. Państwowy Zakład Wydawnictw Lekarskich, Warszawa 1991.

28. Lippi G, van Staden PJ. The use of cyproterone acetate in a forensic psychiatric cohort of male sex offenders and its associations with sexual activity and sexual functioning. S Afr J Psychiatr. 2017; 23: 982.

29. Lopez AM, Weintraub D, Claassen DO. Impulse Control Disorders and Related Complications of Parkinson's Disease Therapy. Semin Neurol 2017; 37: 186-192.

30. Marshall WL, Marshall LE, Serran GA, O’Brien MD. Sexual offender treatment: a positive approach. Psychiatr Clin North Am 2008; 31: 681-696.

31. Montejo-González AL, Llorca G, Izquierdo JA, Ledesma A, Bousoño M, Calcedo A et al. SSRI-induced sexual dysfunction: fluoxetine, paroxetine, sertraline, and fluvoxamine in a prospective, multicenter, and descriptive clinical study of 344 patients. J Sex Marital Ther 1997; 23: 176-194.

32. Odlaug BL, Lust K, Schreiber LR, Christenson G, Derbyshire $\mathrm{K}$, Harvanko A et al. Compulsive sexual behavior in young adults. Ann Clin Psychiatry 2013; 25: 193-200.

33. Quadland MC. Compulsive sexual behavior: definition of a problem and an approach to treatment. J Sex Marital Ther 1985; 11: 121-132.

34. Reddy B, Ali M, Guruprasad S, Das S. Hypersexuality induced by Aripiprazole: Two case reports and review of the literature. Asian J Psychiatr 2018; 38: 57-59.

35. Reid R., Assessing readiness to change among clients seeking help for hypersexual behavior. Sex Addict Compulsivity 2007; 14: 167-186.

36. Rosenberg KP, O'Connor S, Carnes P. Sex addiction: An overview. Behavioral Addiction. Criteria, evidence and treatnemt, Elsevier, London 2014.

37. Ryback RS. Naltrexone in the treatment of adolescent sexual offenders. J Clin Psychiatry 2004; 65: 982-986.

38. Schmidt JG, Schneider WN. Pharmacologic treatment of cognitive deficits and hypersexuality due to "shaken-baby syndrome”. Neurorehabil Neural Repair 2000; 14: 155-158.

39. Schneider JP, Irons RR. Assessment and treatment of addictive sexual disorders: relevance for chemical dependency relapse. Subst Use Misuse 2001; 36: 1795-1820.

40. Schwartz M. Sexual Compulsivity as Post-Traumatic Stress Disorder: Treatment Perspectives. Psychiatr Ann 1992; 22: 333-338.

41. Stein DJ., Classifying hypersexual disorders: compulsive, impulsive, and addictive models. Psychiatr Clin North Am. 2008; 31: 587-591.

42. Voon V, Mole TB, Banca P, Porter L, Morris L, Mitchell S et al. Neural Correlates of Sexual Cue Reactivity in Individuals with and without Compulsive Sexual Behaviours. PLoS ONE 2014; 9:e102419.

43. Zbytovský J. Haloperidol decanoate (Janssen) in the treatment of sexual deviations. Cesk Psychiatr 1993; 89: 15-17. 
